\title{
A Lectin-EGF antibody promotes regulatory $T$ cells and attenuates nephrotoxic nephritis via DC-SIGN on dendritic cells
}

Minchao Cai ${ }^{1,2+}$, Jing $\mathrm{Wu}^{1+}$, Chaoming Mao ${ }^{3,4+}$, Jianmin Ren ${ }^{1}, \mathrm{Pu} \mathrm{Li}^{1}, \mathrm{Xiao}_{\mathrm{Li}}{ }^{2}$, Jiuchang Zhong ${ }^{5}$, Chundi Xu' and Tong Zhou ${ }^{1,2^{*}}$

\begin{abstract}
Background: Interactions between dendritic cells (DCs) and T cells play a critical role in the development of glomerulonephritis, which is a common cause of chronic kidney disease. DC-specific intercellular adhesion molecule-3-grabbing non-integrin (DC-SIGN), an immune-regulating molecule of the C-type lectin family, is mainly expressed on DCs and mediates DC adhesion and migration, inflammation, activation of primary T cells. DC-SIGN triggers immune responses and is involved in the immune escape of pathogens and tumours. In addition, ligation of DC-SIGN on DCs actively primes DCs to induce Tregs. Under certain conditions, DC-SIGN signalling may result in inhibition of DC maturation, by promoting regulatory T cell (Treg) function and affecting Th1/Th2 bias.

Methods: A rat model of nephrotoxic nephritis was used to investigate the therapeutic effects of an anti-lectin -epidermal growth factor (EGF) antibody on glomerulonephritis. DCs were induced by human peripheral blood mononuclear cells in vitro. The expression of DC surface antigens were detected using flow cytometry; the levels of cytokines were detected by ELISA and gPCR, respectively; the capability of DCs to stimulate T cell proliferation was examined by mixed lymphocyte reaction; PsL-EGFmAb targeting to DC-SIGN on DCs was identified by immunoprecipitation.

Results: Anti-Lectin-EGF antibody significantly reduced global crescent formation, tubulointerstitial injury and improved renal function impairment through inhibiting DC maturation and modulating Foxp3 expression and the Th1/Th2 cytokine balance in kidney. Binding of anti-Lectin-EGF antibody to DC-SIGN on human DCs inhibited DC maturation, increased IL-10 production from DCs and enhanced CD4 ${ }^{+} \mathrm{CD} 25^{+}$Treg functions.

Conclusions: Our results suggest that treatment with anti-Lectin-EGF antibody modulates DCs to suppressive DCs and enhances Treg functions, contributing to the attenuation of renal injury in a rat model of nephrotoxic nephritis.
\end{abstract}

Keywords: DC-SIGN, Dendritic cells, Regulatory T cells, Glomerulonephritis

\section{Background}

Glomerulonephritis (GN) is a common cause of renal failure. Tubulointerstitial inflammation is a major contributor of GN progression to renal failure, even in crescentic GN with severe glomerular injury [1,2]. Evidences suggest

\footnotetext{
* Correspondence: zhoutong_cn@hotmail.com

${ }^{\dagger}$ Equal contributors

'Department of Pediatrics, Ruijin Hospital, Shanghai Jiao Tong University School of Medicine, 197 Ruijin Er Road, Shanghai 200025, China

${ }^{2}$ Department of Nephrology, Ruijin Hospital, Shanghai Jiao Tong University

School of Medicine, 197 Ruijin Er Road, Shanghai 200025, China

Full list of author information is available at the end of the article
}

that crescent formation is driven by Th1-dominated nephritogenic immune responses [3-6]. Development of Th1 or Th2 immunity is controlled by dendritic cells (DCs). In different forms of GN, renal function and prognosis closely correlate with the extent of DC infiltration into the tubulointerstitium [7-9].

DCs are critical in the control of immune responses and homoeostasis. Mature DCs induce Th1, Th2 and Th17 effector T-cells, whereas immature DCs drive the development of regulatory $\mathrm{T}$ cells (Tregs), which maintain tolerance to self-antigens and inhibit excessive immune responses by

\section{Biomed Central}


producing IL-10 and TGF- $\beta$ [9-14]. DC maturation is pathogen-specific and exhibits a large degree of plasticity [15]. The nature of the antigen determines the balance towards immunity or tolerance. DCs express a large array of cell surface lectins and lectin-like molecules which are receptors for cognate antigens [16-20]. DC-specific intercellular adhesion molecule-3-grabbing non-integrin (DC-SIGN), a member of the C-type lectin family, mediates DC adhesion and migration, inflammation, activation of primary $\mathrm{T}$ cells, contributes to immune responses and the immune escape of pathogens and tumors [21-23]. DC-SIGN is abundantly expressed on immature DCs (iDCs) and is down-regulated during maturation [21]. DC-SIGN signaling can induce opposite immune responses [18,22,24]. Ligation of DC-SIGN on DCs actively primes DCs to induce Tregs [25]. Thus, targeting DC-SIGN may be a useful strategy to suppress inflammatory responses, which could be beneficial in managing autoimmunity.

Previously we demonstrated that DCs treated in vitro with an anti-lectin-EGF domain monoclonal antibody originally developed against P-selectin (PsL-EGFmAb) displayed low expression of co-stimulatory molecules and an impaired capability to stimulate $\mathrm{CD} 4^{+} \mathrm{T}$ cells [26], indicating suppression of DC maturation and function. However, the underlying mechanism remains unclear. Thus, we administered PsL-EGFmAb to a rat model of nephrotoxic nephritis (NTN), an immune-mediated animal model of human crescentic GN, to investigate whether PsL-EGFmAb could affect DC maturation and Treg- and Th1/Th2-related gene expression in renal tissues, and further investigate the mechanism by which this antibody affects DCs in vitro. We infer that PsLEGFmAb might interact with DC-SIGN that also contains a lectin domain to inhibit DC maturation and induce Tregs that inhibit effector $\mathrm{T}$ cell functions. Our results showed that a lectin-EGF antibody targeting DC-SIGN on dendritic cells promotes regulatory $\mathrm{T}$ cells and attenuates nephrotoxic nephritis.

\section{Methods}

\section{Animals and treatment protocol}

Male 6-8-week old Wistar-Kyoto rats were bred and kept in specific-pathogen-free conditions in an animal facility. Rabbit nephrotoxic serum was generated as described previously [27,28]. The amount of nephrotoxic serum per gram of body weight used in this study (2.0 or $2.5 \mathrm{mg}$ immunoglobulin per gram body weight) was within the linear range of a dose response. Eighteen rats were equally and randomly assigned to three groups and received different injection by tail vein: control group rats injected with normal rat serum; NTN group rats injected with two doses of mouse IgG ( $2 \mu \mathrm{g}$ per gram of rat body weight) at 0 and $2 \mathrm{~h}$ after nephrotoxic serum injection; PsL-EGFmAb-treated group rats received two injections of PsL-EGFmAb, a mouse anti-human monoclonal antibody established in our lab ( $2 \mu \mathrm{g}$ per gram of rat body weight) at 0 and $2 \mathrm{~h}$ after nephrotoxic serum injection. On day 14, the rats were anesthetized with ketamine and sacrificed. Rats in every group were placed in metabolic cages to collect 24 hours urine and detect urine creatinine. Blood was got from inner canthal vein of rats in every group. Serum creatintine (Scr) and urea nitrogen were detected by automatic biochemical analyzer. Creatinine clearance rate $(\mathrm{CCr})$ was got by the formula according to creatintine and urine output in serum and urine. The kidneys were quickly isolated and fixed in $10 \%$ buffered formaldehyde. The study was approved by the Ethics Committee of Ruijin Hospital, Shanghai Jiaotong University School of Medicine.

\section{Renal function studies}

For urine sample collection, rats were housed in metabolic cages. Albuminuria was determined by standard ELISA analysis. Blood samples for blood urea nitrogen (BUN) measurement were obtained at the time of sacrifice. Scr and BUN were measured by standard laboratory methods. Ccr ( $\mathrm{ml} / \mathrm{min}$ ) was used to estimate glomerular filtration rate (GFR).

\section{Periodic Acid Schiff staining}

To evaluate glomerular and tubulointerstitial injury, formalin-fixed rat renal tissue was embedded in paraffin, sectioned at $4 \mu \mathrm{m}$, and stained with Periodic Acid Schiff (PAS) for histological analysis. Tubulointerstitial lesions were scored as follows: 0 , no tubular damage, no interstitial edema; 0.5 , thinning of the brush borders; 1 , thinning of the tubular epithelial; 2 , denudation of the tubular basement membrane; 3 , tubular necrosis.

\section{Analysis of MHC class-II, DC-SIGN and CD80 expressed on renal DCs}

DCs were isolated from rat kidneys as previously described [29]. Briefly, kidneys were finely minced and digested for $45 \mathrm{~min}$ at $37^{\circ} \mathrm{C}$ with $2 \mathrm{mg} / \mathrm{ml}$ collagenase D in RPMI 1640 medium with 10\% heat-inactivated fetal calf serum. Cell suspensions were filtered through 30 $\mu \mathrm{m}$ nylon mesh, and washed with $\mathrm{HBSS}$ without $\mathrm{Ca}^{2+}$ and $\mathrm{Mg}^{2+}$ containing $10 \mathrm{mmol} / \mathrm{L}$ EDTA, $0.1 \% \mathrm{BSA}$ and $10 \mathrm{mM}$ Hepes. Density centrifugation was performed at $1700 \times \mathrm{g}$ for $20 \mathrm{~min}$ at $4^{\circ} \mathrm{C}$ using $1.080 \mathrm{~g} / \mathrm{ml}$ of Nycodenz (Axis-Shield). The interphase cells were harvested and isolated with anti-rat OX62 micro-beads (Miltenyi Biotec, Bergisch Gladbach, Germany). Isolated cells $\left(5 \times 10^{5}\right)$ were stained with FITC- and PE-labeled mAbs specific for MHC class-II and CD80. In addition, $1 \times 10^{5}$ DCs were stained indirectly with DC-SIGN using goat anti-rat DCSIGN polyclonal antibody and PE-conjugated donkey anti-goat IgG mAb. Phenotypic analysis was performed by flow cytometry using a FACS Calibur (BD FACSAria ${ }^{\text {TM }}$ Cell Sorter). 


\section{Real-time PCR assays}

Renal tissue was lysed and total RNA extracted using Trizol reagent (Invitrogen, Carlsbad, CA, USA). cDNA was synthesized using the RevertAid First Strand cDNA Synthesis Kit (Fermentas, Burlington, Canada), following the manufacturer's recommendations. The cycle number at which the fluorescence increased above the threshold was designated as the threshold cycle (CT). Primer specificity was assessed by melting curve. These samples were then analyzed for the expression of IFN- $\gamma$, TNF- $\alpha$, IL-6, IL-4, Foxp3, IL-10, TGF- $\beta$, and GAPDH genes by PCR using the SYBR GREEN PCR Master Mix (Applied Biosystems, Carlsbad, CA, USA) and the ABI PRISM 7700 Sequence Detection System. The sequences of the specific primer pairs used in each case were listed in Table 1. PCR was performed three times as follows: 40 cycles of denaturing at $95^{\circ} \mathrm{C}$ for $15 \mathrm{~s}$ and annealing/extension at $60^{\circ} \mathrm{C}$ for $1 \mathrm{~min}$. Results were normalized to GAPDH expression using the $2^{-\Delta \Delta C t}$ method.

\section{Cell isolation}

PBMCs were obtained from whole blood of healthy donors by Ficoll density gradient centrifugation (Sigma-Aldrich, St. Louis, MO, USA). Then, monocytes were isolated by positive selection with human anti-CD14 microbeads (Miltenyi Biotec), following the manufacturer's instructions. To generate imDCs, isolated $\mathrm{CD} 14^{+}$monocytes $(5 \times$ $10^{5} / \mathrm{ml}$ ) were incubated at $37^{\circ} \mathrm{C}$ for $5-7$ days in RPMI 1640 complete medium (Invitrogen), containing 10\% fetal calf serum and supplemented with $50 \mathrm{ng} / \mathrm{ml}$ human GM-CSF and $20 \mathrm{ng} / \mathrm{ml}$ human IL-4 (R\&D Systems). To obtain $\mathrm{mDCs}$, imDCs were incubated for $48 \mathrm{~h}$ in the presence of $50 \mathrm{ng} / \mathrm{ml}$ TNF- $\alpha$ (R\&D Systems). PsL-EGFmAb $(10 \mu \mathrm{g} / \mathrm{ml})$ was added to the culture $2 \mathrm{~h}$ before TNF- $\alpha$ addition to obtain PsL-EGFmAb-treated DCs. The expression of HLADR, CD80, CD86, CD83 and DC-SIGN on the surface of DCs was confirmed by flow cytometry analysis.

Human $\mathrm{CD}^{+} \mathrm{T}$ cells were isolated from PBMCs by negative selection and the fraction of remaining cells were used to further isolate $\mathrm{CD} 4^{+} \mathrm{CD} 25^{-} \mathrm{T}$ and $\mathrm{CD} 4^{+} \mathrm{CD} 25^{+} \mathrm{T}$ cells by negative and positive selection using a human
$\mathrm{CD} 4{ }^{+} \mathrm{CD} 25^{+}$Treg isolation kit (Miltenyi Biotec), following the manufacturer's instructions.

\section{Flow cytometry analysis}

Expressions of surface antigens on DCs $\left(1 \times 10^{5}\right)$ were assessed with the following mAbs: anti-human HLA-DR and CD83, PE-labeled anti-rat CD80, anti-human CD80 and DC-SIGN, allophycocyanin-labeled anti-human CD86, goat anti-rat DC-SIGN antibody and PE-conjugated donkey anti-goat IgG. Appropriate isotype antibodies were used as controls. The proportion of $\mathrm{CD} 4^{+} \mathrm{CD} 25^{+} \mathrm{Foxp}^{+} \mathrm{T}$ cells in the $\mathrm{CD}^{+} \mathrm{T}$ cell population was determined using a human Treg staining kit (eBioscience), according to manufacturer's instructions. In brief, after CD4 and CD25 surface staining, cells $\left(5 \times 10^{5}\right)$ were washed and fixed at $4^{\circ} \mathrm{C}$ for $60 \mathrm{~min}$ in the dark using fixation/permeabilization solution. Cells were then stained intracellularly for Foxp3.

To investigate whether PsL-EGFmAb can bind to DCSIGN, flow cytometry analysis was performed. First, we used PE-labeled anti-DC-SIGN mAb and PsL-EGFmAb together with FITC-labeled anti-mouse IgG $\mathrm{mAb}$ to detect expression of DC-SIGN on imDCs $\left(1 \times 10^{5}\right)$ separately. Then imDCs were incubated with goat antihuman DC-SIGN antibody for $2 \mathrm{~h}$ before detection of DC-SIGN expression by PsL-EGFmAb together with FITClabeled anti-mouse IgG mAb. The percentage of positive cells was analyzed in a FACSCalibur flow cytometer (BD Biosciences), using Flowjo software (v. 5.7.2, Tree Star Inc., Ashland, OR, USA).

\section{Cytokine assays}

Levels of IFN- $\gamma$, IL-12, TGF- $\beta$, IL-10 and IL- 6 in cell cultures were determined by ELISA (Biosource, Carlsbad, CA, USA). Briefly, cell culture supernatants were collected and the cytokine concentration was analyzed by a specific solid phase sandwich enzyme immunoassay, following the manufacturer's instructions.

\section{Allogeneic mixed cell proliferation assays}

The ability of DCs to stimulate $\mathrm{CD} 4^{+} \mathrm{T}$ cells was assayed by mixed lymphocyte reaction. Allogeneic $\mathrm{CD} 4^{+} \mathrm{T}$ cells

Table 1 Sequences of specific primer pairs

\begin{tabular}{|c|c|c|}
\hline & Forward & Reverse \\
\hline IFN- $\gamma$ & 5'-AACCAGGCCATCAGCAACAAC A -3' & 5'-ACCGACTCCTITCCGCTTCCT-3' \\
\hline TNF-a & 5'-GGTGATCGGTCCCAACAAGGA -3' & 5'-CACGCTGGCTCAGCCACTC-3' \\
\hline IL-6 & 5'-ATATGTTCTCAGGGAGATCTTGGA A-3' & 5'-GTGCATCATCGCTGTTCATACA-3' \\
\hline $\mid \mathrm{L}-4$ & 5'-AACACCACGGAGAACGAGCTC ATC-3' & 5'- AGTGAGTTCAGACCGCTGACACCT -3' \\
\hline Foxp3 & 5'-CCCAGGAAAGACAGCAACCTT -3' & 5'- CTGCTTGGCAGTGCTTGAGAA -3' \\
\hline $\mid \mathrm{L}-10$ & 5'-GCCAAGCCTTGTCAGAAATGA -3' & 5'- TTTCTGGGCCATGGTTCTCT -3' \\
\hline TGF- $\beta$ & 5'-ACCGGGTGGCAGGCGAGAG -3' & 5'- CGGGACAGCAATGGGGGTTCT -3' \\
\hline GAPDH & 5'-AGGACCAGGTTGTCTCCTGT -3' & 5'- TTACTCCTTGGAGGCCATGT -3' \\
\hline
\end{tabular}


$\left(2 \times 10^{5}\right)$ isolated from rat peripheral blood mononuclear cells by magnetic bead-labeled anti-rat CD4 mAb (Miltenyi Biotec) were incubated with irradiated (30 Gy) DCs $\left(2 \times 10^{4}\right)$ isolated from rat kidneys in control, NTN and PsL-EGFmAb-treated groups with anti-rat OX62 micro-beads as mentioned above at a 10:1 ratio in a 96-well U-bottomed plate at $37^{\circ} \mathrm{C}$ for five days. $\mathrm{T}$ cell proliferation was assessed after five days of co-culture by [methyl- ${ }^{3} \mathrm{H}$ ] thymidine $\left(\left[{ }^{3} \mathrm{H}\right] \mathrm{TdR}, 5.0 \mu \mathrm{Ci} / \mathrm{ml}\right)$ incorporation in a $16-\mathrm{h}$ pulse. For this purpose, cells were harvested with a semi automated device, and the incorporation of $\left[{ }^{3} \mathrm{H}\right] \mathrm{TdR}$ was determined in a liquid scintillation counter. Triplicate wells were cultured for each group.

To analyze the stimulatory potential of human DCs on allogeneic $\mathrm{CD} 4^{+} \mathrm{T}, \mathrm{CD} 4^{+} \mathrm{CD} 25^{+} \mathrm{T}$ and $\mathrm{CD} 4^{+} \mathrm{CD} 25^{-} \mathrm{T}$ cells, T cells $\left(2 \times 10^{5}\right)$ were co-cultured for five days with imDCs, mDCs or PsL-EGFmAb-treated DCs $\left(2 \times 10^{4}\right)$. T cells without DC or PsL-EGFmAb treatment were used as a control. $\mathrm{T}$ cell proliferation was assessed as mentioned above. All of these experiments were conducted in triplicate.

\section{Suppression assays}

To analyze the suppressive function of the Tregs induced in vitro by DCs, autologous mixed cell cultures were performed [30]. Briefly, $\mathrm{CD} 4{ }^{+} \mathrm{CD} 25^{+} \mathrm{T}$ cells recovered after five days of co-culture with DCs (T1 cells), were maintained in culture for two additional days in the presence of IL-2 $(50 \mathrm{U} / \mathrm{ml})$ (R\&D Systems). T1 cells or MACS freshly isolated normal human CD $4{ }^{+} \mathrm{CD} 25^{+}$ Tregs $\left(2 \times 10^{5}\right)$ were mixed with autologous $\mathrm{CD}_{4}^{+}$ CD25 $5^{-}$cells $\left(1 \times 10^{5}\right)$ and stimulated with anti-CD3 $(5 \mu \mathrm{g} / \mathrm{ml}) \mathrm{mAb}$ plus anti-CD28 $(1 \mu \mathrm{g} / \mathrm{ml}) \mathrm{mAb}$. After two days of cell culture, $5.0 \mu \mathrm{Ci} / \mathrm{ml}\left[{ }^{3} \mathrm{H}\right] \mathrm{TdR}$ was added and the cells were harvested $16 \mathrm{~h}$ later. Results were expressed as fold increases in $\left[{ }^{3} \mathrm{H}\right] \mathrm{TdR}$ incorporation.

\section{Neutralization assays}

To determine which cytokines secreted by PsLEGFmAb-treated DCs were involved in $\mathrm{CD} 4^{+} \mathrm{CD} 25^{+}$Treg priming, anti-IL-6 $(5 \mu \mathrm{g} / \mathrm{ml})$, anti-IL-10 $(10 \mu \mathrm{g} / \mathrm{ml})$, antiTGF- $\beta(10 \mu \mathrm{g} / \mathrm{ml})$, anti-IL-4 $(10 \mu \mathrm{g} / \mathrm{ml})$, anti-TNF- $\alpha(5 \mu \mathrm{g} /$ $\mathrm{ml})$, anti-IL-12 $(10 \mu \mathrm{g} / \mathrm{ml})$ and anti-IFN- $\gamma(5 \mu \mathrm{g} / \mathrm{ml}) \mathrm{mAbs}$ were used. PsL-EGFmAb-treated DCs $\left(2 \times 10^{4}\right)$ were cocultured with MACS freshly isolated human $\mathrm{CD} 4^{+} \mathrm{CD} 25^{+}$ T cells $\left(2 \times 10^{5}\right)$ for five days in the presence of the different neutralizing antibodies mentioned above. Mouse IgG was also added as an isotype control. $\mathrm{CD} 4^{+} \mathrm{CD} 25^{+} \mathrm{T}$ cells alone were used as a negative control. $\mathrm{T}$ cell proliferation was assessed by $\left[{ }^{3} \mathrm{H}\right] \mathrm{TdR}(5.0 \mu \mathrm{Ci} / \mathrm{ml})$ incorporation in a $16-\mathrm{h}$ pulse. Cells were harvested with a semi automated device, and the incorporation of $\left[{ }^{3} \mathrm{H}\right] \mathrm{TdR}$ was determined in a liquid scintillation counter.

Next, to determine which cytokines secreted by T1 cells inhibited $\mathrm{CD} 4{ }^{+} \mathrm{CD} 25^{-}$effector $\mathrm{T}$ cell proliferation, the same neutralizing antibodies at similar doses were used. PsLEGFmAb-treated DC-induced T1 cells $\left(2 \times 10^{5}\right)$ were co-cultured with $1 \times 10^{5}$ MACS freshly isolated human $\mathrm{CD} 4^{+} \mathrm{CD} 25^{-} \mathrm{T}$ cells for five days in the presence of different neutralizing antibodies. Mouse IgG was also added as an isotype control, while $\mathrm{CD} 4^{+} \mathrm{CD} 25^{-} \mathrm{T}$ cells alone were used as a negative control. $\mathrm{T}$ cell proliferation was assessed using the method mentioned above. All of these experiments were conducted in triplicate and the results were expressed as fold increases in $\left[{ }^{3} \mathrm{H}\right] \mathrm{TdR}$ incorporation.

\section{siRNA Sequences (DC-SIGN)}

Sequences of various siRNAs used are as follows: DCSIGN antisense, 5'-ATT TGT CGT CGT TCC AGC CAT-3'; DC-SIGN sense, 5'-ATG GCT GGA ACG ACA CAA A-3'; DC-SIGN antisense scrambled control, 5'-CAC ACC ACA TCT TTC CGT CAC-3'; DC-SIGN sense scrambled control, 5' -GTG ACG GAA AGA TGT GGT G-3'. RNA oligonucleotides were custom synthesized by Dharmacon Research Inc (Lafayette, CO, USA) with an overhang of 2 thymidine residues $(\mathrm{dTdT})$ at the 3 ' end. The RNA oligonucleotides were dissolved in Tris-EDTA (10 mM Tris- $\mathrm{HCl}, \mathrm{pH} 8.0$; and $1 \mathrm{mM}$ EDTA) as $200 \mu \mathrm{M}$ solutions and were stored at $-20^{\circ} \mathrm{C}$. Double-stranded siRNA molecules were generated by mixing the corresponding pair of sense and antisense RNA oligonucleotides in annealing buffer (30 mM HEPES-KOH, pH 7.9; $100 \mathrm{mM}$ potassium acetate; and 2 $\mathrm{mM}$ magnesium acetate) at $20 \mu \mathrm{M}$ and then by incubating the reaction mixture at $95^{\circ} \mathrm{C}$ for $2 \mathrm{~min}$, followed by gradual cooling to room temperature. The siRNAs were then aliquoted and stored at $-20^{\circ} \mathrm{C}$.

\section{Transfection of siRNAs}

Twenty-four-hours before siRNA transfection, DCs $\left(1 \times 10^{6}\right)$ were seeded in 6-well plates in OPTI-minimal essentials medium (OptiMEM; Invitrogen, Grand Island, NY, USA) containing $10 \%$ fetal bovine serum (FBS) with no antibiotics. Cells were seeded per 6-well plate to give $30 \%$ to $50 \%$ confluency at the time of the transfection. The siRNAs were transfected at a final concentration of $50 \mathrm{nM}$ using Oligofectamine (Invitrogen) according to the manufacturer's recommendations. The control (untransfected) cells received either Oligofectamine alone or Oligofectamine plus scrambled sequence. The siRNAs added to control cells were incubated for 24-48 and 72 hours and the cells were harvested and RNA was extracted.

\section{Immunoprecipitation}

ImDCs $\left(5 \times 10^{5}\right)$ were lysed in lysis buffer ( $1 \%$ Triton-X100, $10 \mathrm{mM}$ TEA pH 8.2, $150 \mathrm{mM} \mathrm{NaCl}, 1 \mathrm{mM} \mathrm{MgCl}_{2}$ and $1 \mathrm{mM} \mathrm{CaCl}_{2}$ ) containing a cocktail of EDTA-free protease inhibitors for $1 \mathrm{~h}$ at $4^{\circ} \mathrm{C}$. Cell lysates were immunoprecipitated with PsL-EGFmAb-coated or mouse 
IgG-coated Agarose A/G beads (Pierce, Appleton, WI, USA), following the manufacturer's instructions. Briefly, cell lysates were incubated with PsL-EGFmAb-coated or mouse IgG-coated beads overnight at $4^{\circ} \mathrm{C}$ on an orbital shaker. The beads were then collected and washed three times with $800 \mu \mathrm{l}$ of ice-cold PBS followed by pulse centrifugation. After washing, beads were resuspended in $60 \mu \mathrm{l}$ of $2 \times$ sample buffer and gently mixed. DC-SIGN was detected by western blotting using the protocol mentioned above. Cell lysates without immunoprecipitation were used as positive controls.

\section{Statistical analysis}

SPSS software, version 11.0, was used for statistical analyses. Data are presented as the mean \pm SD. Statistically significant differences between groups were determined using the Student's $t$ test or Mann-Whitney $U$-test, as appropriate. A value of $p<0.05$ was considered significant.

\section{Results}

PsL-EGFmAb treatment attenuates renal lesions and improves renal function in a rat model of NTN

A rat model of NTN was established and used to test the therapeutic effect of PsL-EGFmAb [31]. Rats injected with nephrotoxic serum developed typical NTN inflammation on day 14 after induction, characterized by enlarged glomeruli, global cellular crescent formation in more than $50 \%$ of glomeruli $(59.41 \pm 2.22 \%, p<0.01)$ destruction of Bowman's capsule wall, abruption of the basement membranes of glomeruli and tubules, interstitial edema and diffuse inflammatory cell infiltration (Figure 1A). Compared to control rats injected with IgG, rats treated with PsL-EGFmAb showed attenuated glomerular and tubulointerstitial lesions (Figure 1A and 1B). The proportion of glomeruli with crescent formation was significantly reduced $(33.90 \pm 6.46 \%, p<0.01)$.

Twenty-four-hour urinary proteins (Figure 1C), Scr (Figure 1D) and BUN (Figure 1E) of nephritic rats were significantly elevated, and Ccr (Figure $1 \mathrm{~F}$ ) was significantly decreased on day 14 compared with non-nephritic controls $(p<0.01)$. In the PsL-EGFmAb-treated group, we observed a significant reduction in levels of urinary 24-hour proteins, BUN and Scr, and increased Ccr levels compared with the NTN group $(p<0.01)$, indicating that PsL-EGFmAb treatment improved renal function.

\section{PsL-EGFmAb treatment inhibits renal DC maturation}

To investigate whether treatment of PsL-EGFmAb could inhibit DC maturation in vivo, renal DCs were freshly isolated at two weeks. Injection of rats with rabbit nephrotoxic serum significantly up-regulated MHC class-II and CD80 expression but down-regulated DC-SIGN expression

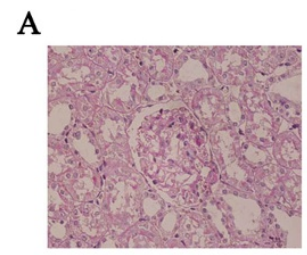

Control

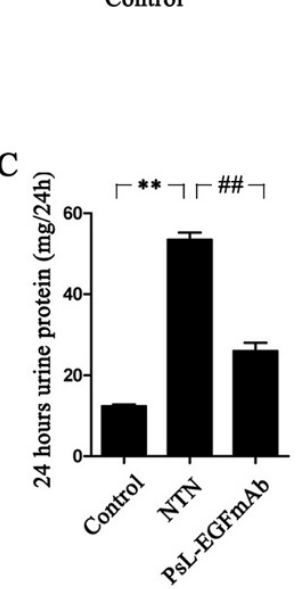

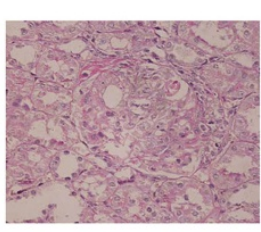

NTN

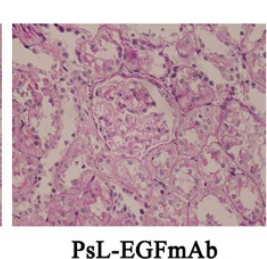

PsL-EGFmAb
B
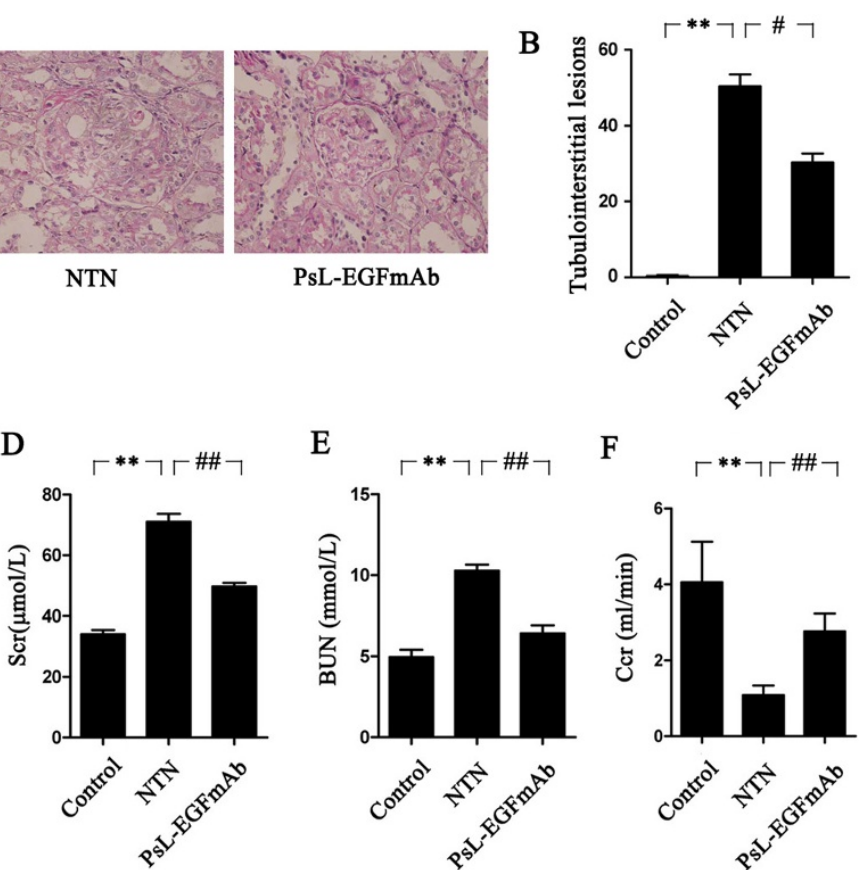

$\mathrm{E}$

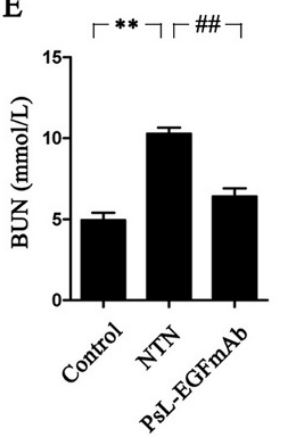

F

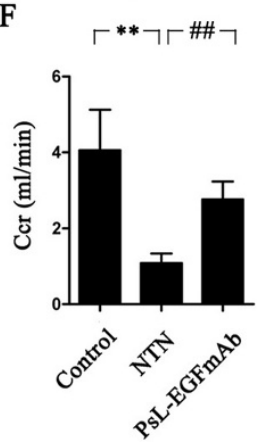

Figure 1 Effect of PsL-EGFmAb on renal pathology and function. A, PAS staining of renal tissues and corresponding quantification (final magnification $\times$ 200). Renal tissues were harvested on day 14. B, Tubulointerstitial damage was evaluated according to the scoring system we mentioned in the Methods. C-F, Twenty-four-hour urine proteins (C), Scr (D) and BUN (E) of nephritic rats were significantly elevated, whereas CCr (F) levels were significantly reduced on day 14 compared with non-nephritic controls $(p<0.01)$. PsL-EGFmAb treatment significantly reduced twenty-four -hour urine proteins $(\mathbf{C}), \operatorname{Scr}(\mathbf{D})$, BUN (E) levels and increased $\mathrm{CCr}(\mathbf{F})$ compared with NTN group $(p<0.01)$, indicating improvement of renal function after PsL-EGFmAb treatment. The mean \pm SD of three independent experiments is shown. ${ }^{* *} p<0.01$ vs. control; ${ }^{\#} p<0.05$, ${ }^{\# \#} p<0.01$ vs. NTN group. 
on renal DCs compared with controls. Treatment with PsL-EGFmAb significantly down-regulated DC-SIGN and CD80 expression and slightly decreased MHC class-II expression on DCs compared with controls treated with non-specific IgG. DC-SIGN expression was decreased after treatment with PsL-EGFmAb (Figure 2, A-C). The ability of DCs from the rat NTN group to stimulate T cells significantly improved but was reduced in the PsLEGFmAb-treated group (Figure 2D). This suggests that PsL-EGFmAb treatment significantly inhibited DC-SIGN expression and DC maturation in the rat NTN group.

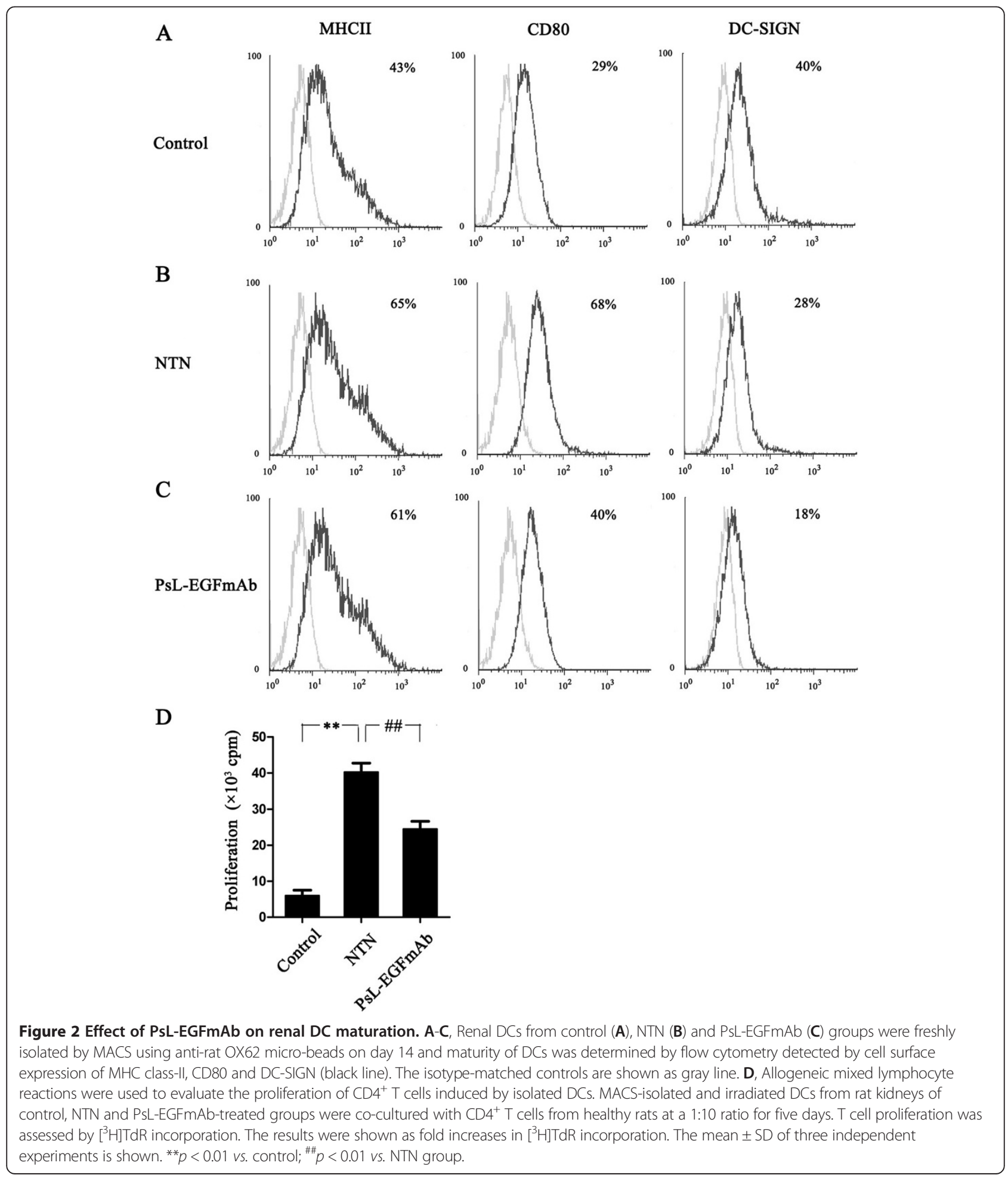


PsL-EGFmAb treatment inhibits inflammatory cytokine expression, shifts the Th1/Th2 cytokine profile and upregulates Treg-related gene expression in renal tissues We measured the expression of three pro-inflammatory cytokines, interferon (IFN)- $\gamma$ (Figure 3A), tumor necrosis factor (TNF)- $\alpha$ (Figure 3B) and interleukin (IL)-6 (Figure 3C) in renal tissues by real-time PCR. Administration of rabbit nephrotoxic serum to rats induced significant expression of all three cytokines compared with controls $(p<0.05)$. Interestingly, the expression of all three cytokines was significantly decreased in rats treated with PsL-EGFmAb compared rats from the NTN group $(p<0.05)$, indicating that PsL-EGFmAb elicits an anti-inflammatory effect in the rat NTN model.

We next investigated the Th1/Th2 cytokine profile. Non-immunized rats displayed a Th2-dominated cytokine profile characterized by higher levels of IL-4 (Figure 3D) compared to IFN- $\gamma$. Although injecting rats with rabbit nephrotoxic serum induced significant IL-4 and IFN- $\gamma$ secretion $(p<0.05)$, the increase in IFN- $\gamma$ expression was much higher than IL-4, indicating a switch from a Th2- to a Th1-dominated profile (Figure 3A, D, H). Interestingly, PsL-EGFmAb treatment not only decreased IFN- $\gamma$ expression, but also reversed the IFN- $\gamma / \mathrm{IL}-4$ ratio compared with the rat NTN group (Figure $3 \mathrm{~A}, \mathrm{D}, p<0.05$ ).

It is well established that Tregs can inhibit both Th1 and Th2 type immune responses. To further explore the cause of decreased levels of inflammatory cytokines after PsL-
EGFmAb treatment, we investigated the expression of Treg-related factors such as Foxp3, IL-10 and TGF- $\beta$ in renal tissues. There was a significant down-regulation of Foxp3 expression (Figure 3E) after rats were injected with the rabbit nephrotoxic serum $(p<0.05)$, whereas PsLEGFmAb treatment significantly up-regulated Foxp3 expression in both the NTN group and non-immunized rats $(p<0.05)$, indicating the possible up-regulation of Tregs after PsL-EGFmAb treatment. We then examined expression of IL-10 and TGF- $\beta$, the two main cytokines promoting Treg priming. Injecting rats with rabbit nephrotoxic serum significantly up-regulated IL-10 expression (Figure 3F) $(p<0.05)$, and PsL-EGFmAb treatment further increased IL-10 expression compared with the NTN group $(p<0.05)$. There was no significant difference in TGF- $\beta$ expression among the three groups (Figure 3G). Together, these results suggest that PsL-EGFmAb treatment in the rat NTN model enhanced Treg function, and that IL-10 expression might be involved.

\section{PsL-EGFmAb inhibits human DC maturation in vitro}

The in vivo data above suggested that alleviation of inflammation resulting from PsL-EGFmAb treatment was associated with a reversed Th1/Th2 cytokine profile, and was potentially the result of Treg up-regulation. DCs determine differentiation of Th0 cells to Th1 or Th2 phenotype. DCs at different maturation stages have different roles in $\mathrm{T}$ cell differentiation [32]. To further probe the
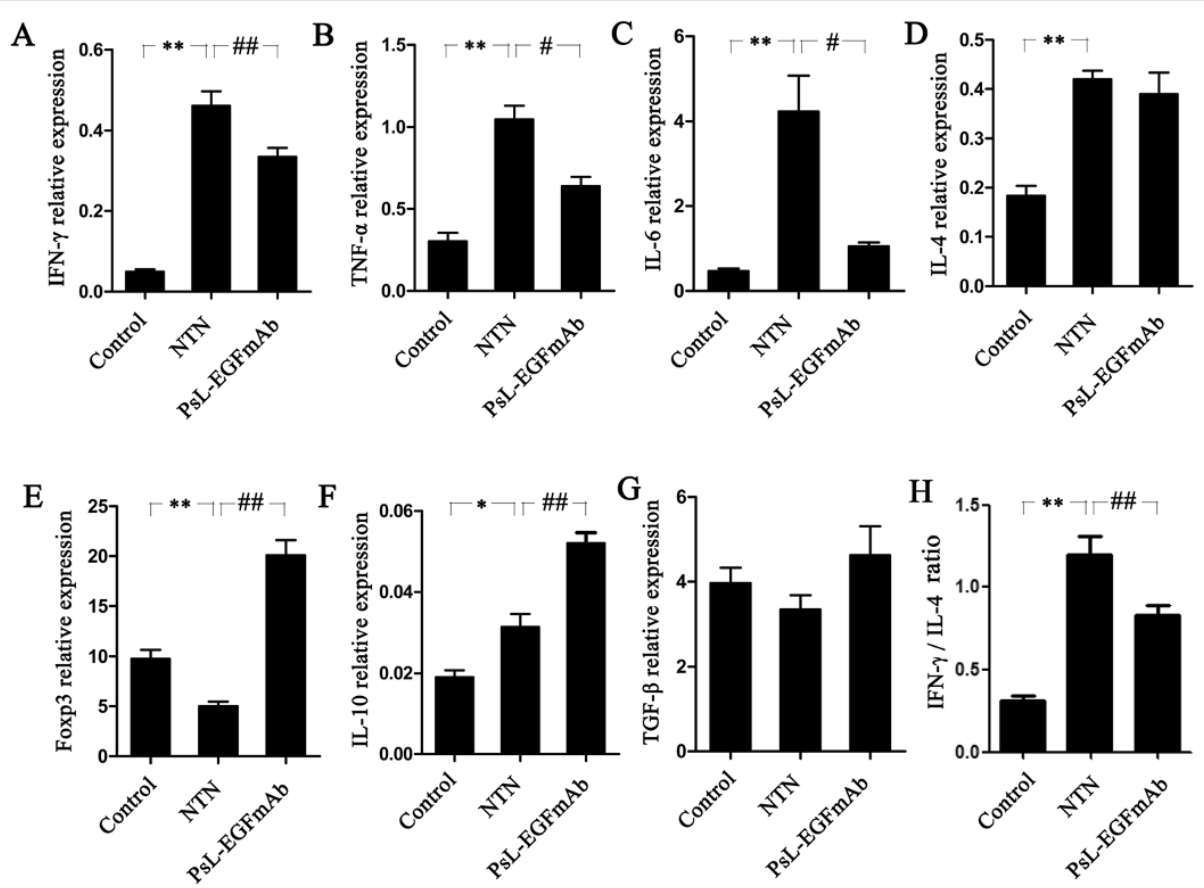

Figure 3 The mRNA expression of cytokines in renal tissues. Real-time PCR for IFN- $\gamma(\mathbf{A})$, TNF-a (B), IL-6 (C), IL-4 (D), Foxp3 (E), IL-10 (F), TGF- $\beta$ (G) mRNA expression and IFN- $\gamma / \mathrm{IL}-4$ ratio $(\mathbf{H})$ in renal tissues. Expression of the genes of interest was normalized to that of the GAPDH gene, and described as $2^{-\Delta \Delta \mathrm{Ct}}$. The mean \pm SD of four independent experiments is shown. ${ }^{*} p<0.05,{ }^{* *} p<0.01 \mathrm{vs}$. control; ${ }^{\#} p<0.05$, ${ }^{\# \#} p<0.01 \mathrm{vs}$. NTN group. 
potential mechanism by which PsL-EGFmAb treatment affects $\mathrm{T}$ cell functions, we used an in vitro system and investigated whether PsL-EGFmAb could affect DC maturation. As shown in Figure 4, A-C, flow cytometric analysis revealed that PsL-EGFmAb-treated DCs exhibited lower expression of CD80, CD86 and CD83 compared with TNF- $\alpha$-induced mature DCs (mDCs). There was no difference in human leukocyte antigen (HLA)-DR expression between DCs with or without PsL-EGFmAb treatment (Figure 4, A-C).

\section{PsL-EGFmAb treatment promotes Treg priming mediated by DCs in vitro}

To further investigate the effect of PsL-EGFmAb on DCmediated $\mathrm{T}$ cell priming, $\mathrm{CD} 4^{+} \mathrm{T}$ cells, $\mathrm{CD} 4^{+} \mathrm{CD} 25^{+}$Tregs and $\mathrm{CD} 4^{+} \mathrm{CD} 25^{-} \mathrm{T}$ cells were freshly isolated from human peripheral blood mononuclear cells (PBMCs) of healthy adults using MACS. Isolated T cells were co-cultured with imDCs, mDCs or TNF- $\alpha$ plus PsL-EGFmAb-treated DCs. Allogeneic mixed cell proliferation assays revealed that imDCs slightly increased the proliferation of all three types of $\mathrm{T}$ cells. In contrast, $\mathrm{mDCs}$ significantly increased proliferation of both $\mathrm{CD} 4^{+} \mathrm{T}$ cells and $\mathrm{CD} 4^{+} \mathrm{CD} 25^{-}$effector $\mathrm{T}$ cells, but failed to increase $\mathrm{CD} 4^{+} \mathrm{CD} 25^{+}$Treg proliferation compared with imDCs. Interestingly, PsL-EGFmAb-treated DCs displayed totally different characteristics to mDCs. PsL-EGFmAb-treated DCs significantly promoted CD4 ${ }^{+}$ $\mathrm{CD} 25^{+}$Treg proliferation and inhibited any further increase in $\mathrm{CD}^{+}{ }^{+} \mathrm{T}$ cell and $\mathrm{CD} 4^{+} \mathrm{CD} 25^{-}$effector $\mathrm{T}$ cell proliferation $(p<0.05)$ (Figure 5, A-C). Flow cytometric

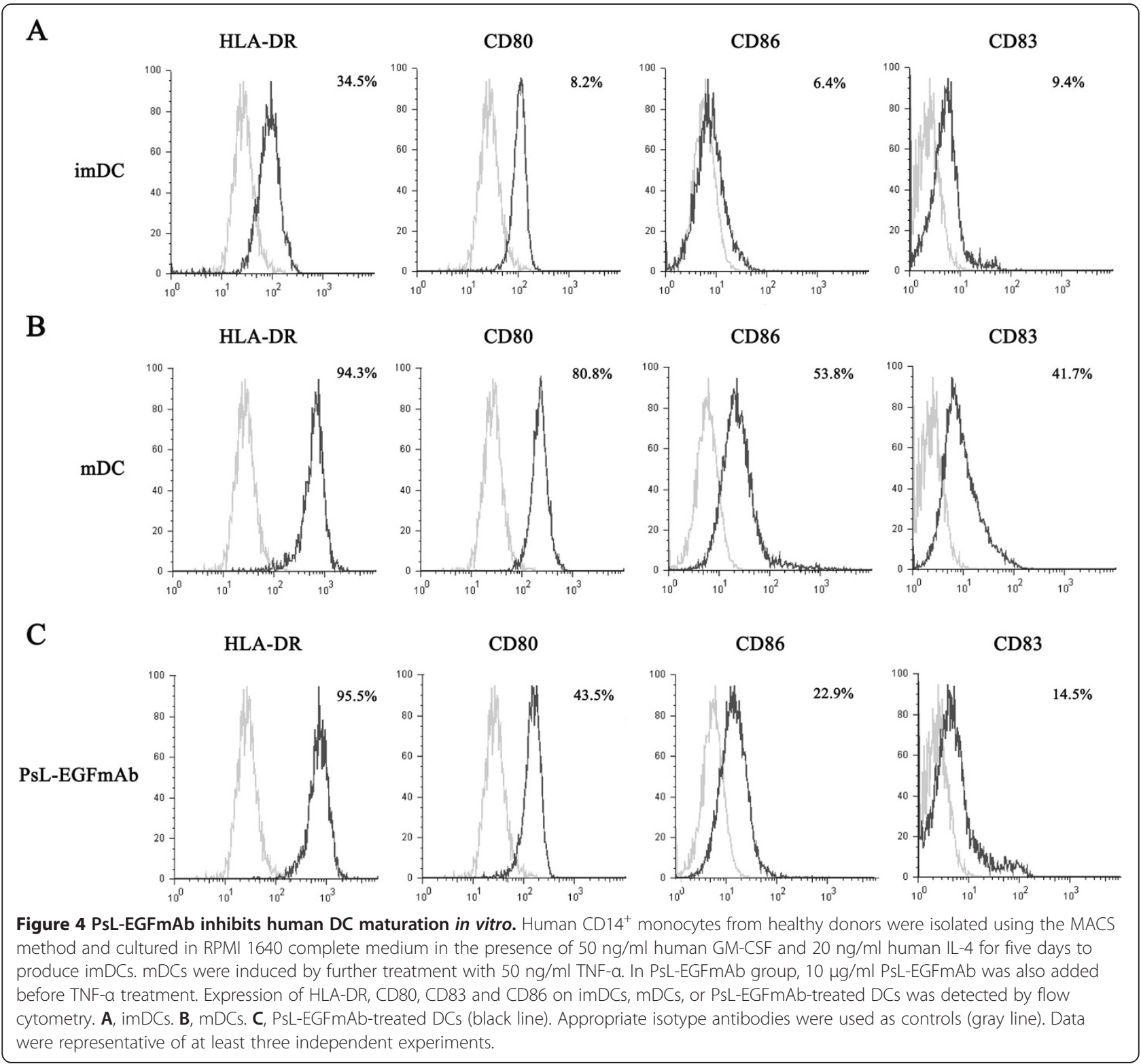


A

$\mathrm{CD}^{+} \mathrm{T}$

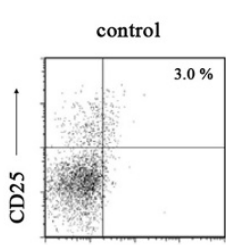

Foxp3 $\longrightarrow$

B

$\mathrm{CD}^{+}{ }^{+} \mathrm{CD} 25^{+} \mathrm{T}$
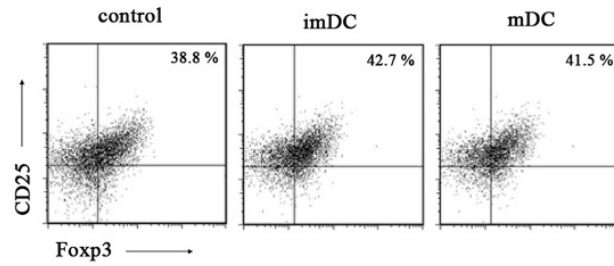

PsL-EGFmAb

-treated DC

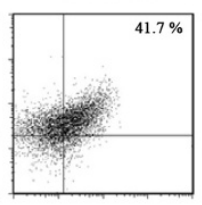

$\mathrm{C}$

$\mathrm{CD}^{+}{ }^{+} \mathrm{CD} 25-\mathrm{T}$

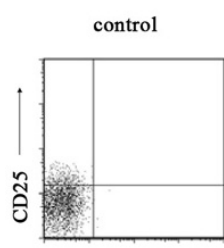

imDC

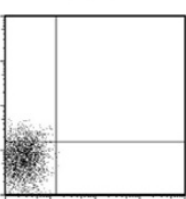

Foxp3
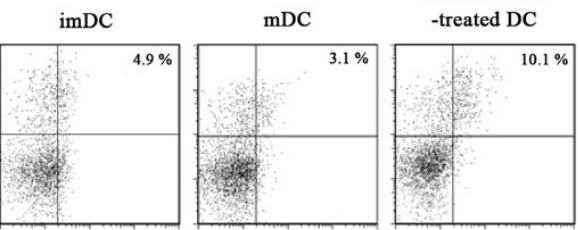

学
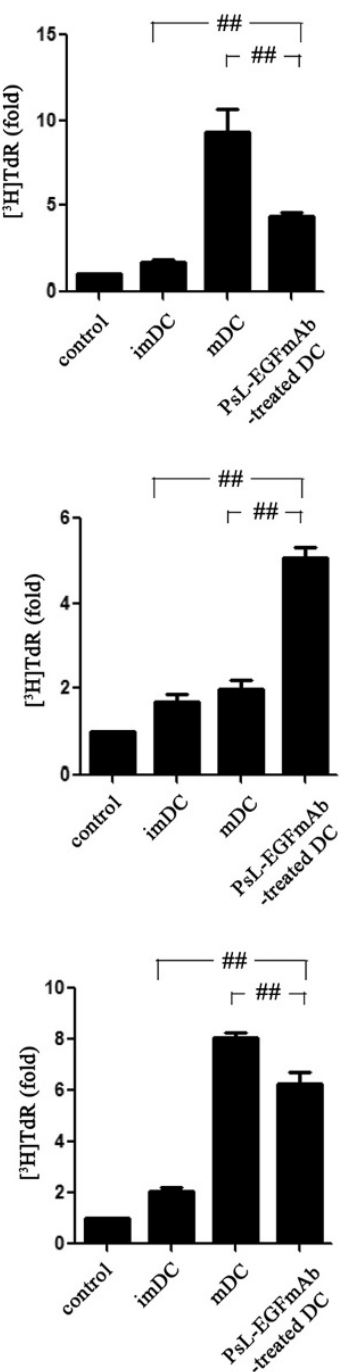

D

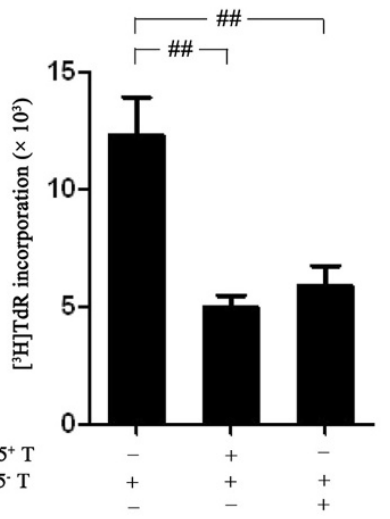

Figure 5 Allogeneic mixed T cell proliferation assays. imDCs, mDCs or PSL-EGFmAb-treated mDCs were co-cultured with freshly isolated human $\mathrm{CD}^{+}, \mathrm{CD}^{+} \mathrm{CD} 25^{+}$and $\mathrm{CD} 4^{+} \mathrm{CD} 25^{-} \mathrm{T}$ cells, respectively, then proliferation assays were performed and the results are shown as fold increases in $\left[^{3} \mathrm{H}\right] \mathrm{TdR}$ incorporation. Flow cytometric analysis was also performed to detect CD4 ${ }^{+} \mathrm{CD} 25^{+}$Foxp3 ${ }^{+}$Tregs. A, DCs co-cultured with CD4 ${ }^{+} \mathrm{T}$ cells. B, DCs co-cultured with $C D 4^{+} \mathrm{CD} 25^{+} \mathrm{T}$ cells. C, DCs co-cultured with $\mathrm{CD} 4^{+} \mathrm{CD} 25^{-} \mathrm{T}$ cells. D, A suppression assay was performed to evaluate the suppressive function of CD4 ${ }^{+} \mathrm{CD} 25^{+} \mathrm{T}$ cells using the same method. Tregs were either co-cultured with PsL-EGFmAb-treated mDCs (T1) or freshly isolated from health adults. The mean \pm SD of four independent experiments is shown. ${ }^{\#} p<0.05,{ }^{\# \#} p<0.01$. 
analysis revealed that PsL-EGFmAb-treated DCs also increased the percentage of $\mathrm{CD} 4{ }^{+} \mathrm{CD} 25^{+} \mathrm{Foxp} 3^{+} \mathrm{T}$ cells after co-culture with $\mathrm{CD} 4^{+} \mathrm{T}$ cells (Figure $5 \mathrm{~A}$ ). $\mathrm{CD} 4^{+} \mathrm{CD} 25^{+} \mathrm{Foxp}^{+}$ $\mathrm{T}$ cells were almost undetectable when DCs were co-cultured with $\mathrm{CD} 4{ }^{+} \mathrm{CD} 25^{-}$effector T cells (Figure $5 \mathrm{C}$ ).

Next, we investigated whether proliferating $\mathrm{CD} 4{ }^{+} \mathrm{CD} 25^{+}$ Tregs after co-culture with PsL-EGFmAb-treated DCs (T1 cells) could exhibit the same suppressive function as freshly isolated $\mathrm{CD}^{+} \mathrm{CD} 25^{+}$Treg cells. Both T1 cells and freshly isolated $\mathrm{CD} 4{ }^{+} \mathrm{CD} 25^{+}$Treg cells significantly inhibited $\mathrm{CD} 4{ }^{+} \mathrm{CD} 25^{-}$effector $\mathrm{T}$ cell proliferation $(p<$ 0.05 ) determined by suppression assay, indicating T1 cells and freshly isolated $\mathrm{CD} 4{ }^{+} \mathrm{CD} 25^{+}$Treg cells exhibited the same suppressive function (Figure 5D).

\section{IL-10 secreted by PsL-EGFmAb-treated DCs contributes to induction of Tregs}

To investigate whether cytokines secreted by DCs were involved in the priming of Tregs, an enzyme-linked immunosorbent assay (ELISA) assay and neutralizing assay were performed. First we detected cytokines secreted by DCs subjected to different treatments. All DCs, despite differences in treatments, secreted low levels of IFN- $\gamma$ (Figure 6A) and moderate levels of TGF- $\beta$ (Figure $6 \mathrm{E}$ ). There were no significant differences among these groups $(p>0.05)$. mDCs secreted much higher levels of IL-12 (Figure 6B) and IL-6 (Figure 6C) compared with imDCs $(p<0.05)$. However, PsL-EGFmAb treatment dramatically reduced IL-6 secretion $(p<0.05)$ but not IL-12. Although mDCs also secreted IL-10 compared with imDCs $(p<0.05)$, treatment of mDCs with PsL-EGFmAb significantly increased IL-10 secretion (Figure 6D) $(p<0.05)$. These results suggested that changes in cytokine production following PsL-EGFmAb treatment might be involved in Treg cell priming.

Next we used neutralizing antibodies to block the action of cytokines secreted by DCs to determine which cytokines were involved in Treg cell priming. Freshly isolated $\mathrm{CD}_{4}^{+} \mathrm{CD} 25^{+}$Treg cells were co-cultured with PsL-EGFmAb-treated DCs in the presence of different neutralizing antibodies. $\mathrm{CD} 44^{+} \mathrm{CD} 25^{+}$Treg cell proliferation was significantly inhibited in the presence of anti-IL-10 neutralizing antibody, whereas anti-IL-6, anti-TGF- $\beta$, anti-IL-4, anti-TNF- $\alpha$, anti-IL-12 and anti-IFN- $\gamma$ mAbs failed to inhibit cell proliferation, indicating that IL-10 was the key cytokine for Treg cell priming (Figure 6F).

A suppression assay confirmed these results. $\mathrm{CD} 4{ }^{+} \mathrm{CD} 25^{+}$ $\mathrm{T}$ cells were co-cultured with PsL-EGFmAb-treated DCs for two days before freshly isolated $\mathrm{CD} 4^{+} \mathrm{CD} 25^{-} \mathrm{T}$ cells were

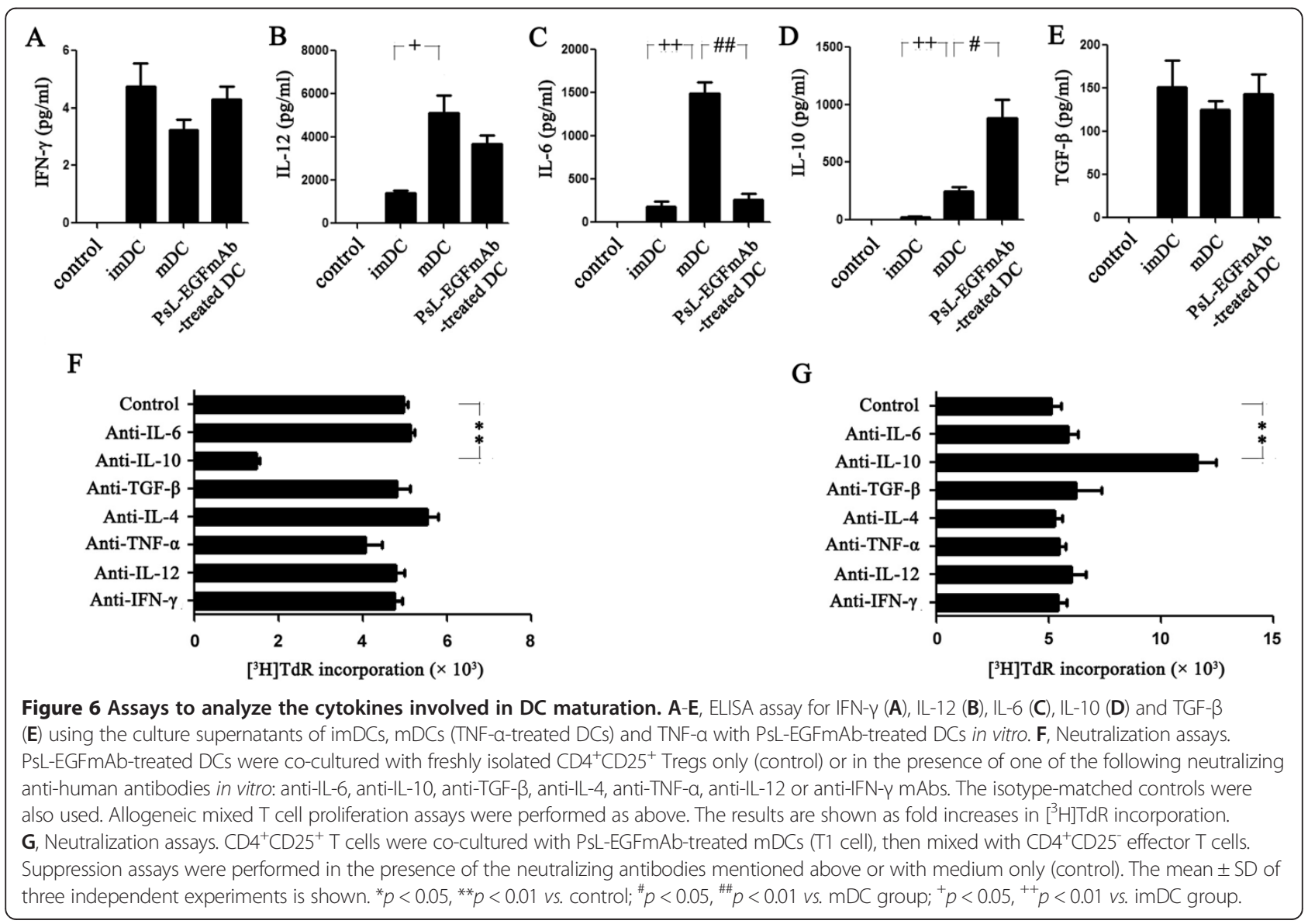


added in the presence of different neutralizing antibodies. Compared to the isotype IgG-treated group, co-cultured $\mathrm{CD} 4^{+} \mathrm{CD} 25^{+} \mathrm{T}$ cells failed to inhibit $\mathrm{CD} 4^{+} \mathrm{CD} 25^{-} \mathrm{T}$ cell proliferation in the presence of anti-IL-10 neutralizing antibody, whereas anti-IL- 6 , anti-TGF- $\beta$, anti-IL-4, anti-TNF- $\alpha$, anti-IL-12 and anti-IFN- $\gamma$ mAbs had no significant effect on cell proliferation (Figure 6G), indicating that IL-10 was involved in supporting the suppressive function of Tregs.

\section{PsL-EGFmAb targets DCs through DC-SIGN}

Our data indicate that PsL-EGFmAb treatment could affect DC maturation and function, subsequently affecting Treg priming and function. Next, we investigated how PsL-EGFmAb signaled to DCs. We measured DCSIGN expression on imDCs by flow cytometry using fluorescence-labeled DC-SIGN mAb and PsL-EGFmAb respectively. We also pre-incubated imDCs with anti-DCSIGN goat antiserum to prevent binding of PsL-EGFmAb to DCs before staining with fluorescence labeled-PsLEGFmAb. A similar percentage of positive cells were detected with both mAbs (Figure 7, A-C). Pre-incubation of DCs with anti-DC-SIGN goat antiserum to block DCSIGN on DCs before detection, dramatically reduced the number of positive cells, indicating that PsL-EGFmAb likely binds to DC-SIGN on DCs.

To confirm this, immunoprecipitation was performed. DCs with or without DC-SIGN siRNA were lysed, and DC lysates immunoprecipitated with PsL-EGFmAb-coated beads. DC-SIGN was detected in immunoprecipitated DC lysates, similar to the positive control. This further supported the interaction between PsL-EGFmAb and DCSIGN (Figure 7D, E).
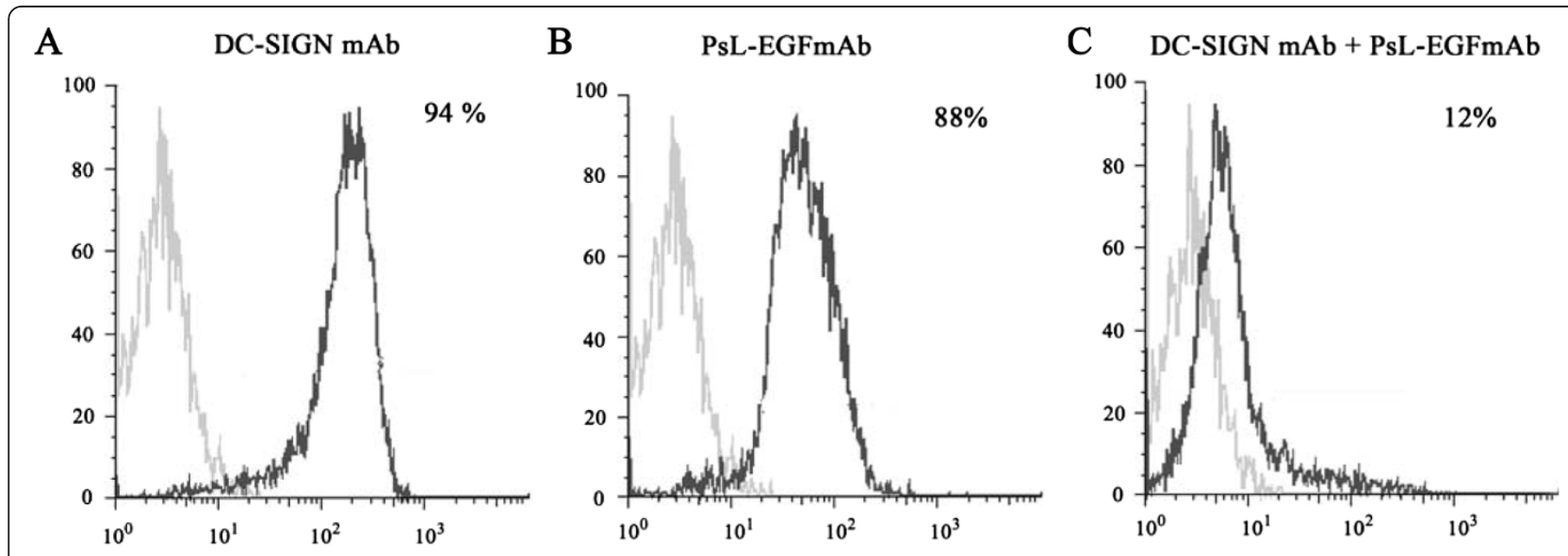

D

DCs without DC-SIGN siRNA

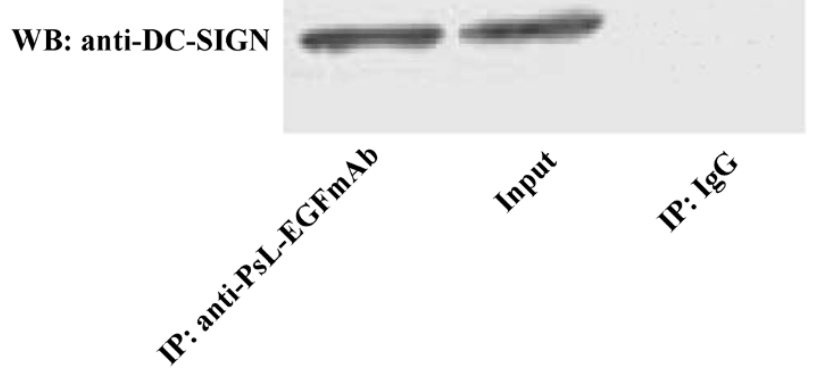

$\mathrm{E}$

\section{DCs with DC-SIGN siRNA}

Figure 7 PsL-EGFmAb signals to DCs through DC-SIGN. A-C, We generated human monocyte-derived DCs by incubating MACS-isolated CD14 ${ }^{+}$ monocytes from healthy donor blood with GM-CSF and IL-4 for 5 days (imDCs). Flow cytometry detected DC-SIGN expression on imDCs using fluorescence-labeled DC-SIGN mAb (A) and PSL-EGFmAb (B) respectively. C, imDCs pre-incubated with anti-DC-SIGN goat antiserum were also included to prevent binding of PsL-EGFmAb to DCs before staining with PSL-EGFmAb. D. Western blotting analysis of DC-SIGN in different samples: imDC lysates immunoprecipitated using PSL-EGFmAb-coated beads (left), imDC lysates without immunoprecipitation (middle), imDC lysates immunoprecipitated using mouse lgG-coated beads (right). Experiments were performed in triplicate and the data from one representative experiment is shown. $\mathbf{E}$, Western blotting analysis of DC-SIGN from different samples: The lysates of imDCs with DC-SIGN siRNA were immunoprecipitated using PsL-EGFmAb-coated beads (left), the lysates of imDCs with DC-SIGN siRNA without immunoprecipitation (middle), the lysates of imDCs with DC-SIGN siRNA immunoprecipitated using mouse lgG-coated beads (right). 


\section{Discussion}

NTN is an animal model of human crescentic GN, characterized by glomerular crescent formation, tubulointerstitial inflammation, impaired renal function and proteinuria $[1,2,33]$. Several studies demonstrated that a Th1-dominated nephritogenic immune response is responsible for the formation of crescents [1,2]. Recently, the protective role of Tregs in GN has been demonstrated [34]. It is well established that DCs play a critical role in the development of tubulointerstitial inflammation by modulating Th0 cells to Th1, Th2 or Th17 polarization [35], or limiting inflammation by promoting Tregs [36].

In the present study, we demonstrated that treatment with PsL-EGFmAb led to a reversal of the Th1-dominated cytokine mRNA expression profile and attenuation of renal lesions in a rat model of NTN. This was accompanied by improvement of renal function indicating that the protective effect likely involved the inhibition of DC maturation, and subsequent $\mathrm{T}$ cell differentiation. DCs have an important role in peripheral tolerance by various mechanisms, including activation of Tregs, induction of $\mathrm{T}$ cell anergy and skewed Th1/Th2 differentiation [37,38]. Increasing evidence suggests that DC functions are associated with maturation status $[39,40]$. Fully matured DCs are efficient activators of $\mathrm{T}$ cells, while imDCs have been implicated in anergy induction [41]. An intermediate stage of DC maturation was recently described, where DCs express relatively high levels of MHC class-II and co-stimulatory molecules, but do not secrete proinflammatory cytokines [42]. Previously we showed that treatment of DCs with PsL-EGFmAb , an anti-lectin-EGF domain monoclonal antibody originally developed against P-selectin, led to suppression of DC maturation and inhibition of $\mathrm{CD}^{+}{ }^{+} \mathrm{T}$ cell proliferation in vitro [24]. In the present study we further demonstrated the suppression of DC maturation and $\mathrm{T}$ cell stimulation after PsL-EGFmAb treatment ex vivo, and interestingly observed an upregulation of Foxp3 and IL-10 expression in renal tissues from rat NTN. Together, treatment of PsLEGFmAb inhibited DC maturation, which could in turn induce Treg differentiation and regulate Th1/Th2 bias.

To further characterize the effect of PsL-EGFmAb on DCs, we used human DCs that comprehensively reflected DC maturation and functions. Our results suggested that treating DCs with PsL-EGFmAb could drive DCs to an intermediate maturation stage assessed by expression of intermediate levels of co-stimulatory molecules. DCs at this maturation stage may be capable of inducing immune tolerance.

Promotion of Tregs is one mechanism by which DCs regulate immune tolerance. We therefore investigated whether PsL-EGFmAb-treated DCs could promote $\mathrm{CD} 4{ }^{+} \mathrm{CD} 25^{+}$Treg development. PsL-EGFmAb-treated DCs suppressed $C D 4^{+} \mathrm{T}$ cell proliferation by stimulating the expansion of $\mathrm{CD} 4^{+} \mathrm{CD} 25^{+}$Tregs. This raised the question of whether PsL-EGFmAb-treated DCs promoted $\mathrm{CD} 25^{+}$Treg proliferation or induced $\mathrm{CD} 25^{+}$Treg differentiation from $\mathrm{CD} 25^{-} \mathrm{T}$ cells. To address this question, we sorted $\mathrm{CD} 4^{+} \mathrm{CD} 25^{-} \mathrm{T}$ cells and cultured them with PsL-EGFmAb-treated DCs. PsL-EGFmAb-treated DCs failed to differentiate $\mathrm{CD} 4{ }^{+} \mathrm{CD} 25^{-}$cells into $\mathrm{CD} 4{ }^{+} \mathrm{CD} 25^{+}$ Tregs, but stimulated the expansion of primary $\mathrm{CD} 4^{+} \mathrm{CD} 25^{+}$ Tregs. Furthermore, the expanded $\mathrm{CD}^{+} \mathrm{CD} 25^{+}$Tregs displayed the same ability to suppress $\mathrm{T}$ cell function as freshly isolated $\mathrm{CD} 4{ }^{+} \mathrm{CD} 25^{+}$Tregs.

IL-10 and TGF- $\beta$ are immunoregulatory cytokines which facilitate the generation of murine and human Tregs [32]. Chronic activation of murine and human $\mathrm{CD}^{+}{ }^{+} \mathrm{T}$ cells in the presence of IL-10 results in the generation of Tregs [43]. When polarized, these cells can inhibit in vitro and in vivo alloresponses [43]. In the present study, the addition of neutralizing anti-IL$10 \mathrm{mAb}$ significantly inhibited $\mathrm{CD} 4{ }^{+} \mathrm{CD} 25^{+} \mathrm{T}$ cell proliferation induced by PsL-EGFmAb-treated DCs, and attenuated their suppressive function on $\mathrm{CD} 4^{+} \mathrm{CD} 25^{-} \mathrm{T}$ cells. Antibodies against other cytokines had no effect, indicating a critical role of IL-10 in the promotion of Tregs by PsL-EGFmAb-treated DCs. Conversely, the above phenomenon was not seen with neutralizing anti-TGF- $\beta$ mAbs.

According to the in vivo and in vitro data, we speculated that PsL-EGFmAb treatment could inhibit DC maturation in renal tissue or draining lymph nodes, to induce the generation of tolerogenic DCs, which can inhibit Th1/Th2 polarization and promote Treg proliferation by IL-10. These events together could lead to the alleviation of inflammation in renal tissue.

Next we determined which molecule on DCs interacted with PsL-EGFmAb. As PsL-EGFmAb affected DC maturation and function, this indicated that it might interact directly with DCs. As DC-SIGN has a similar lectin domain to P-selectin in its molecular structure, it may interact with PsL-EGFmAb. To test this, we compared the binding of PsL-EGFmAb and DC-SIGN mAb to DCs by flow cytometry, and found that both mAbs showed similar levels of binding. Furthermore, DCs, in which DC-SIGN was blocked by anti-DC-SIGN goat antiserum, led to dramatically reduced binding of PsL-EGFmAb. This was also supported by results from the immunoprecipitation study using PsL-EGFmAb-labeled micro beads which clearly showed that PsL-EGFmAb bound to DC-SIGN. Together, our data clearly demonstrate that PsL-EGFmAb binds to DC-SIGN on imDCs, although it can also bind to molecules containing a lectin domain. Besides DC-SIGN, PsLEGFmAb might interact with other molecules possessing lectin or EGF domains on DCs, contributing to the immune regulation of DCs. All above are required further studies to analyze such functions. 


\section{Conclusions}

Our findings revealed a potential regulatory effect of PsL-EGFmAb, an anti-lectin-EGF domain monoclonal antibody originally developed against P-selectin, on immune responses including anti-inflammatory effects and regulation of immune reaction through DC-SIGN expressed by DCs. PsL-EGFmAb-treated DCs display an immature profile, capable of promoting $\mathrm{CD} 4{ }^{+} \mathrm{CD} 25^{+}$ Treg expansion and inhibiting $\mathrm{CD}^{+}$effector $\mathrm{T}$ cell proliferation in vitro. The administration of PsL-EGFmAb to a rat NTN model, attenuated renal immune lesions accompanied by a skewed Th1/Th2 cytokine profile and up-regulation of Treg-related Foxp3 expression, which may have resulted from the generation of tolerogenic DCs by PsL-EGFmAb treatment. Our results suggest that PsL-EGFmAb could be a potential therapeutic treatment for human kidney diseases.

\begin{abstract}
Abbreviations
DCs: Dendritic cells; DC-SIGN: DC-specific intercellular adhesion molecule-3 -grabbing non-integrin; Treg: Regulatory T cell; EGF: Epidermal growth factor; GN: Glomerulonephritis; iDCs: Immature DCs; NTN: Nephrotoxic nephritis; BUN: Blood urea nitrogen; Ccr: Creatinine clearance; GFR: Glomerular filtration rate; PAS: Periodic Acid Schiff; FBS: Fetal bovine serum; IFN: Interferon; TNF: Tumor necrosis factor; mDCs: Mature DCs; HLA: Human leukocyte antigen; PBMCs: Peripheral blood mononuclear cells; ELISA: Enzyme-linked immunosorbent assay.
\end{abstract}

\section{Competing interests}

All the authors declared no competing interests.

\section{Authors' contributions}

TZ and CDX conceived the study design, participated in its design and in the acquisition of data. MCC, JW and CMM carried out the experiments, participated in the acquisition of data, analysis and interpretation, drafted the manuscript. PL have been involved in analyzing the data and provided critical advice. JMR have been involved in revising figures. JCZ and XL helped to draft and revise the manuscript. All authors read and approved the final manuscript

\section{Acknowledgements}

This work was supported by the National Natural Science Foundation of China (39970340, 30770999, 81170246, 81270801). We thank Xiaodong Xi and Dangsheng Li for their critical reading of the manuscript.

\section{Author details}

${ }^{1}$ Department of Pediatrics, Ruijin Hospital, Shanghai Jiao Tong University School of Medicine, 197 Ruijin Er Road, Shanghai 200025, China. ${ }^{2}$ Department of Nephrology, Ruijin Hospital, Shanghai Jiao Tong University School of Medicine, 197 Ruijin Er Road, Shanghai 200025, China. ${ }^{3}$ Shanghai Institute of Immunology and Institute of Health Sciences, Shanghai Jiao Tong University School of Medicine, 227 South Chongqing Road, Shanghai 200025, China. ${ }^{4}$ Department of Nuclear Medicine, The Affiliated Hospital of Jiangsu University, 438 Jiefang Road, Zhenjiang 212001, China. ${ }^{5}$ State Key Laboratory of Medical Genomics and Shanghai Institute of Hypertension, Ruijin Hospital, Shanghai Jiaotong University School of Medicine, 197 Ruijin Er Road, Shanghai 200025, China.

Received: 14 December 2012 Accepted: 25 April 2013 Published: 29 April 2013

\section{References}

1. Rodriguez-Iturbe B, Johnson RJ, Herrera-Acosta J: Tubulointerstitial damage and progression of renal failure. Kidney Int Supp/ 2005, 68:S82-S86.

2. Liu Y: Renal fibrosis: new insights into the pathogenesis and therapeutics. Kidney Int 2006, 69:213-217.
3. Huang XR, Tipping PG, Shuo L, Holdsworth SR: Th1 responsiveness to nephritogenic antigens determines susceptibility to crescentic glomerulonephritis in mice. Kidney Int 1997, 51:94-103.

4. Holdsworth SR, Kitching AR, Tipping PG: Th1 and Th2 T helper cell subsets affect patterns of injury and outcomes in glomerulonephritis. Kidney Int 1999, 55:1198-1216.

5. Kitching AR, Holdsworth SR, Tipping PG: Crescentic glomerulonephritis-a manifestation of a nephritogenic Th1 response? Histol Histopathol 2000, 15:993-1003.

6. Summers SA, Steinmetz OM, Li M, Kausman JY, Semple T, Edqtton KL, Borza DB, Braley H, Holdsworth SR, Kitching AR: Th1 and Th17 cells induce proliferative glomerulonephritis. J Am Soc Nephrol 2009, 20:2518-2524.

7. Segerer S, Heller F, Lindenmeyer MT, Schmid H, Cohen CD, Draganovici D, Mandelbaum J, Nelson PJ, Gröne HJ, Gröne EF, Figel AM, Nössner E, Schlöndorff D: Compartment specific expression of dendritic cell markers in human glomerulonephritis. Kidney Int 2008, 74:37-46.

8. Kim AH, Markiewicz MA, Shaw AS: New roles revealed for T cells and DCs in glomerulonephritis. J Clin Invest 2009, 119:1074-1076.

9. Panzer $U$, Kurts $C$ : T cell cross-talk with kidney dendritic cells in glomerulonephritis. J Mol Med 2010, 88:19-26.

10. Usharauli D: Dendritic cells and the immunity/tolerance decision. Med Hypotheses 2005, 64:112-113.

11. Kaiko GE, Horvat JC, Beagley KW, Hansbro PM: Immunological decisionmaking: how does the immune system decide to mount a helper T-cell response? Immunology 2008, 123:326-338.

12. Lebre MC, Tak PP: Dendritic cell subsets: their roles in rheumatoid arthritis. Acta Reumatol Port 2008, 33:35-45.

13. Frick JS, Grunebach F, Autenrieth IB: Immunomodulation by semi-mature dendritic cells: a novel role of Toll-like receptors and interleukin-6. Int J Med Microbiol 2010, 300:19-24.

14. Kapsenberg ML: Dendritic-cell control of pathogen-driven T-cell polarization. Nature reviews 2003, 93:984-993.

15. Huang Q, Liu D, Majewski P, Schulte LC, Korn JM, Young RA, Lander ES, Hacohen N: The plasticity of dendritic cell responses to pathogens and their components. Science 2001, 294:870-875.

16. van Kooyk Y: C-type lectins on dendritic cells: key modulators for the induction of immune responses. Biochem Soc Trans 2008, 36:1478-1481.

17. Geijtenbeek TB, den Dunnen J, Gringhuis SI: Pathogen recognition by DC-SIGN shapes adaptive immunity. Future Microbiol 2009, 4:879-890.

18. Geijtenbeek TB, van Vliet SJ, Engering A, 't Hart BA, van Kooyk Y: Self- and nonself-recognition by C-type lectins on dendritic cells. Annu Rev Immunol 2004, 22:33-54.

19. Chang SY, Kweon MN: Langerin-expressing dendritic cells in gut-associated lymphoid tissues. Immunol Rev 2010, 234:233-246.

20. Kerrigan AM, Brown GD: Syk-coupled C-type lectin receptors that mediate cellular activation via single tyrosine based activation motifs. Immunol Rev 2010, 234:335-352.

21. Svajger U, Anderluh M, Jeras M, Obermajer N: C-type lectin DC-SIGN: an adhesion, signalling and antigen-uptake molecule that guides dendritic cells in immunity. Cell Signal 2010, 22:1397-1405.

22. Svajger U, Obermajer N, Anderluh M, Kos J, Jeras M: DC-SIGN ligation greatly affects dendritic cell differentiation from monocytes compromising their normal function. J Leukocyte Biol 2011, 89:893-905.

23. Zhou T, Chen Y, Hao L, Zhang Y: DC-SIGN and immunoregulation. Cell Mol Immunol 2006, 3:279-283.

24. van Stijn CM, Meyer S, van den Broek M, Bruijns SC, van Kooyk Y, Geyer R, van Die I: Schistosoma mansoni worm glycolipids induce an inflammatory phenotype in human dendritic cells by cooperation of TLR4 and DC-SIGN. Mol Immunol 2010, 47:1544-1552.

25. Smits HH, Engering A, van der Kleij D, de Jong EC, Schipper K, van Capel TM, Zaat BA, Yazdanbakhsh M, Wierenga EA, van Kooyk Y, Kapsenberg ML: Selective probiotic bacteria induce IL-10-producing regulatory $T$ cells in vitro by modulating dendritic cell function through dendritic cell-specific intercellular adhesion molecule 3-grabbing nonintegrin. J Allergy Clin Immun 2005, 115:1260-1267.

26. Zhou T, Zhang Y, Sun G, Zou J, Li X, Cai M, Xiao Y, Zhang Y, Zhao Y, Chen $\mathrm{N}$ : PsL-EGFmAb inhibits the stimulatory functions of human dendritic cells via DC-SIGN. Front Biosci 2008, 13:7269-7276.

27. Zhou T, Song W, Wang F, Ni PH, Chen N, Zhang DQ, Yu QW: Cloning, expression of the Lectin-EGF domain of P-selectin, and preparation of its monoclonal antibody. Acta Biochimica et Biohysica Sinica 2003, 35:172-176. 
28. Assmann KJ, Tangelder MM, Lange WP, Schrijver G, Koene RA: Anti-GBM nephritis in the mouse: severe proteinuria in the heterologous phase. Virchows Arch A Pathol Anat Histopathol 1985, 406:285-299.

29. Kruger T, Benke D, Eitner F, Lang A, Wirtz M, Hamilton-Williams EE, Engel D, Giese B, Müller-Newen G, Floege J, Kurts C: Identification and functional characterization of dendritic cells in the healthy murine kidney and in experimental glomerulonephritis. J Am Soc Nephrol 2004, 15:613-621.

30. Baeke F, Korf H, Overbergh L, Verstuyf A, Thorrez L, Van Lommel L, Waer M, Schuit F, Gysemans C, Mathieu C: The vitamin D analog, TX527, promotes a human $\mathrm{CD} 4+\mathrm{CD} 25$ highCD127low regulatory $T$ cell profile and induces a migratory signature specific for homing to sites of inflammation. $\mathrm{J}$ Immuno/ 2011, 186:132-142.

31. Satchell SC, Buchatska O, Khan SB, Bhangal G, Tasman CH, Saleem MA, Baker DP, Lobb RR, Smith J, Cook HT, Mathieson PW, Pusey CD: Interferonbeta reduces proteinuria in experimental glomerulonephritis. J Am Soc Nephrol 2007, 18:2875-2884.

32. Rutella S, Lemoli RM: Regulatory T cells and tolerogenic dendritic cells: from basic biology to clinical applications. Immunol Lett 2004, 94:11-26.

33. Bohle A, Strutz F, Muller GA: On the pathogenesis of chronic renal failure in primary glomerulopathies: a view from the interstitium. Exp Nephrol 1994, 2:205-210.

34. Wolf D, Hochegger K, Wolf AM, Rumpold HF, Gastl G, Tilg H, Mayer G, Gunsilius E, Rosenkranz AR: $\mathrm{CD} 4^{+} \mathrm{CD} 25^{+}$regulatory T cells inhibit experimental anti-glomerular basement membrane glomerulonephritis in mice. J Am Soc Nephrol 2005, 16:1360-1370.

35. Kurts C, Heymann F, Lukacs-Kornek V, Boor P, Floege J: Role of T cells and dendritic cells in glomerular immunopathology. Semin Immunopathol 2007, 29:317-335.

36. Morelli AE, Thomson AW: Tolerogenic dendritic cells and the quest for transplant tolerance. Nat Rev Immunol 2007, 7:610-621.

37. Jonuleit H, Schmitt E, Steinbrink K, Enk AH: Dendritic cells as a tool to induce anergic and regulatory T cells. Trends Immunol 2001, 22:394-400.

38. Steinman RM, Hawiger D, Nussenzweig MC: Tolerogenic dendritic cells. Annu Rev Immunol 2003, 21:685-711.

39. Lutz MB, Schuler G: Immature, semi-mature and fully mature dendritic cells: which signals induce tolerance or immunity? Trends Immunol 2003, 23:445-449.

40. Mahnke K, Schmitt E, Bonifaz L, Enk AH, Jonuleit H: Immature, but not inactive: the tolerogenic function of immature dendritic cells. Immunol Cell Biol 2002, 80:477-483.

41. Steinman RM, Nussenzweig MC: Avoiding horror autotoxicus: the importance of dendritic cells in peripheral T cell tolerance. Proc Natl Acad Sci U S A 2002, 99:351-358.

42. Menges M, Rossner S, Voigtlander C, Schindler H, Kukutsch NA, Bogdan C, Erb K, Schuler G, Lutz MB: Repetitive injections of dendritic cells matured with tumor necrosis factor alpha induce antigen-specific protection of mice from autoimmunity. J Exp Med 2002, 195:15-21.

43. Groux H, O'Garra A, Bigler M, Rouleau M, Antonenko S, de Vries JE, Roncarolo MG: A CD4+ T-cell subset inhibits antigen-specific T-cell responses and prevents colitis. Nature 1997, 389:737-742.

doi:10.1186/1479-5876-11-103

Cite this article as: Cai et al:: A Lectin-EGF antibody promotes regulatory $T$ cells and attenuates nephrotoxic nephritis via

DC-SIGN on dendritic cells. Journal of Translational Medicine 2013 11:103.

\section{Submit your next manuscript to BioMed Central and take full advantage of:}

- Convenient online submission

- Thorough peer review

- No space constraints or color figure charges

- Immediate publication on acceptance

- Inclusion in PubMed, CAS, Scopus and Google Scholar

- Research which is freely available for redistribution

Submit your manuscript at www.biomedcentral.com/submit 